\title{
MEANINGS OF CARE IN HEALTH PROMOTION
}

Gladys Carmela Santos Falcón ${ }^{1}$

Alacoque Lorenzini Erdmann ${ }^{2}$

Dirce Stein Backes ${ }^{3}$

Falcón GCS, Erdmann AL, Backes DS. Meanings of care in health promotion. Rev Latino-am Enfermagem 2008 maio-junho; 16(3):419-24.

The objective of the study is to understand the meaning built by students and professors on health promotion in the teaching and learning process of health care in Nursing. It is a qualitative study using ground theory as a methodological reference. Data was collected through interviews, with three samples groups, 13 students and four professors, by classroom observation, and through meetings with nursing professors. The central subject resulting from this analysis was: constructing teaching and learning in order, disorder and self organization for a new way of caring promoting health. The teaching/learning process directed at health promotion develops in a stage of crisis, going from a state of order to a state of disorder that is uncertain and contradictory regarding what society understands about health.

DESCRIPTORS: health promotion; education, nursing; public health

\section{SIGNIFICADOS DEL CUIDAR EN LA PROMOCIÓN DE LA SALUD}

El estudio tuvo por objetivo comprender los significados construidos por los alumnos y docentes sobre la promoción de la salud en el proceso de enseñar/aprender el cuidado en Enfermería. Se trata de un estudio cualitativo teniendo como referencial metodológico la Teoría Fundamentada en los Datos. Los datos fueron obtenidos por medio de una entrevista en grupos de tres muestras, con trece alumnos y cuatro docentes de enfermería, a través de la observación en la sala de clases y durante las reuniones de los docentes. Del análisis surgió como tema central: construyendo el enseñar y aprender en orden, desorden y durante la autoorganización para promover la salud a través de una nueva forma de cuidar. El proceso de enseñanza/ aprendizaje dirigido a la promoción de la salud se desarrolla durante una etapa de crisis, yendo de un estado de orden a un estado de desorden, que es incierto y contradictorio con relación a lo que la sociedad entiende por salud.

DESCRIPTORES: promoción de la salud; educación en enfermería; salud pública

\section{SIGNIFICADOS DO CUIDAR NA PROMOÇÃO DA SAÚDE}

O estudo objetivou compreender os significados construídos pelos alunos e docentes sobre a promoção da saúde no processo de ensinar/aprender o cuidado de enfermagem. Trata-se de estudo qualitativo, tendo como referencial metodológico a Teoria Fundamentada nos Dados. Os dados foram obtidos por meio de entrevista, em três grupos amostrais, treze alunos e quatro docentes, e por meio da observação em sala de aula e nas reuniões dos docentes do Curso de Enfermagem. Do resultado dessa análise emergiu como tema central: construindo o ensinar e aprender na ordem, desordem e auto-organização para nova forma de cuidar, promovendo a saúde. O processo ensino/aprendizagem, encaminhado para promoção da saúde, desenvolvese numa etapa de crise, indo de estado de ordem ao estado de desordem, que é incerto e contraditório quanto ao que a sociedade entende por saúde.

DESCRITORES: promoção da saúde; educação em enfermagem; saúde pública

${ }^{1}$ Ph.D. in Nursing, Faculty, Universidad Nacional Mayor de San Marcos, Peru, e-mail: gladys50@yahoo.com.br; ${ }^{2}$ RN, Ph.D. in Nursing Philosophy, Ful Professor, e-mail: alacoque@newsite.com.br; ${ }^{3}$ RN, Doctoral student, e-mail: backesdirce@ig.com.br. Santa Catarina Federal University, Brazil 


\section{INTRODUCTION}

The present study started from questions we asked regarding the education of health professionals in general and, especially, nursing professionals. Among the topics that made us reflect with work colleagues, both in care, and in the university, were those related with the changes in our society in the last years that reflected on health, therefore, with a complex reality caused by several factors.

In this sense, we believed that future professionals, among them, nursing professionals, should be aware of these changes and of the general context and health professionals, especially professors, should make epidemiological and/or methodological proposals to give answers to the needs of society regarding health. Due to the complexity of education, we believe that problems should be studied with different approaches and theories, considering the multiple interrelations of the health aspects.

We can understand that there are issues that are broad, deep and severe between knowledge on one side, divided, and disconnected, and the reality on the other, with problems that are multidisciplinary, cross-sectional, multidimensional, transnational, global, and planetary ${ }^{(1)}$. We may say that in this problem, the context, the global, the multidimensional, and the context become invisible.

With this regards, we can see changes in the curriculum of the nursing course to form students with a broad view on health, considering not only the healing aspects of the disease. We believe that this new curriculum should be studied to asses how students are grasping this knowledge, and the meanings they are building for health promotion. Based on these other questions, the present study aimed at understanding the meanings built by students and professors on health promotion in the process of teaching/learning about care on the Subjects Processo Viver Humano I e II (Human Living Process I) and (Human Living Process II).

\section{METHODOLOGY}

We searched for a reference that enabled understanding the problematic of the object that is in a complex reality, with multidimensional problems and several interactions between the social actors involved in the teaching/learning process (professors and students) identifying the Theory of Complexity developed by Morin and followers in all fields of knowledge.

The grounded theory (GT) was the methodological reference used to reach the goal of coming up with a theory based on the experiences of professors and students of the subjects previously mentioned. The theory is formed with data systematically stored and analyzed through an investigation process. In GT data collection, analysis, and the theory derived from them have a close correlation $^{(2)}$.

The study was performed at the Nursing Course of a Federal University in the South of Brazil, this institution was chosen because it was developing a new curriculum, with health promotion as a central axes. Data collection occurred in the second semester of 2005 and first of 2006.

Data were collected through a theoretical sample to create the theory, where investigator collects, codes, and analysis data, deciding which data will be collected next and where to find them, to develop the theory that is being formed. Theoretical saturation was reached with 17 individuals among students on the first phase (four) and second phase (nine), and professors (four) of subjects Human Living Process I (first phase) and Human Living II (second phase) of the Nursing Course. Interviewees were divided into 3 sample groups, following GT recommendations.

For data analysis, codification in its three moments was proposed: Open coding, axial coding, and selective coding ${ }^{(2)}$. We have considered data obtained by participant observation in the classroom with students and in meeting room with professors, interviews, and those obtained by researcher, such as observations notes, theoretical notes and methodological notes.

Data were organized according to the paradigmatic model, establishing causal categories, the context, the intervening conditions, strategic actions, and the consequences of the phenomenon, paying attention to the several connections between categories and categories, categories and subcategories until the phenomena was structured ${ }^{(3)}$.

Previous contacts were established with principals of the institutions to inform them about the procedures. Thus, the project followed the recommendations of Regulation 196/96 of the National Health Council, that presents on the individual and 
collective perspective the 4 basic principles of bioethics: autonomy, non-maleficence, beneficence, and justice, among others, as well as ensure rights and duties concerning the scientific community, the individuals of the research, and the State ${ }^{(4)}$. The project was approved by the Ethical Research Committee of the Federal University of Santa Catarina, under number 0273/05.

To preserve confidentiality of actors involved, significant contributions have been identified, in the text, with changed names.

\section{DISCUSSION AND RESULT ANALYSIS}

In the beginning of the study at the Nursing Course, that aims at educating students according the guidelines of the Ministry of Health and with emphasis in basic health, in the subject Human Living Process I, different perceptions of students regarding their education to promote health were found. Most of them considered the themes approached in the classroom as too philosophical and with little use in the professional life. On the other hand, a small number of students considered the themes necessary to understand human beings that they will care for in their professional lives. This contradiction may be understood $^{(5)}$ when we see that different people can define the same situation in different ways, because the meaning given to objects varies from one person to another. I believe theory is important, because in the first phase you have to have theory, Philosophy, because it helps us think (Cristal).

The way people define situation depends, also, on their background, which is unique to each person. Students' background depends on their previous experience regarding health, their readings, talks with parents, friends, and relatives. We have observed that the students that referred to the themes as necessary were those with previous experience in health, such as disease of a relative, or themselves, or previous experience in courses, or, those who wanted to learn about new things, because of their age, as shown by the following statements: I knew from my father, he had an infarct, then, I stayed with him in the Hospital (Topázio). It is about growing, evolving, getting older and wanting to learn new things on environment, individual health, and collective health (Safira).

In the study, evident changes were seen in second phase students when some of them said they considered the themes developed important, both in the subject Human Living I and II. Students understand the nature of care as they care for human beings that need to be understood and this will demand familiarity with themes that they call philosophical. In the first phase you are already presented with new ideas, you change your mind, you change the ideas you use to have (Ouro).

To think about the complexity, we must consider the four words: order, disorder, interaction, and organization that are present in the universe, in human history in all its sides ${ }^{(6)}$. In this sense, disorder means deviations that appear in any process, changing it in a way. They are the shocks, the accidents, unpredictability, disintegration, agitations, what is unexpected. Regarding the spirit, disorder is explained by uncertainty and the author considers it as essential to evolvement.

In the teaching/learning process for health promotion, this last meeting between two organized phenomena may be seen both in students, and professors. For students taking part in the research, order is to look at reality with a biological view that comes from the imaginary of society, and within this order, nurses are those working only in hospitals, performing technical activities.

In the university, this order is broken when students take Human Living Process I with themes such as human beings, the environment, health/ disease process, environmental sanitation, and other subjects related with health promotion. Students are shocked; their health conceptions are disorganized because they do not relate these themes with nursing work, they have nothing to do with the professional image of nurses they bring to university. Therefore, in the classes of this subject they are against these themes, they reject them complaining they are far too abstract, and that they take too long, because it has nothing to teach them: In Process I, I wondered what is this subject for? If I am going to work with people with psychological, neurological problems, and they are talking about life, Philosophy, why they are doing this, we questioned (Ouro).

From disorder and interaction established with the different objects (Physical, Social, and Abstract) in the development of the first subjects (Human Living Process I and Human Living Process II), the transformation process begins. This means that students self-organize their knowledge and, when they start the second phase, they can give meaning to their background because they see there are other ways of caring for health, and to develop them, they 
need to review their conceptions. Thus, they need to discuss philosophical issues. As Agata's statement shows: Until the first semester, I believed Philosophy had nothing to do with nursing, because I could not see a connection in Living Process I, then I did not think it was significant because that did not tell me anything. Now, at Living Process II, we start to understand that nursing is not only practical, you have to know, you have to know how to approach patients, and for that, you need Philosophy, you must treat people well (Ágata).

On the other hand, professors also experienced this four-word process: order, disorder, interaction, and organization during the development of teaching/learning for health promotion. They experience a situation of order in teaching when they teach subjects related with what they expect from students, such a Pediatric Nursing, for example. In these cases, students are willing to learn a show it, because they consider it as part of the nursing education, and part of their imaginary.

The disorder situation for professors is presented in the development of the subject Human Living Process I, when most students, despite their professors' effort, are not enthusiastic or even refuse to learn the themes developed in the classroom, considering them too "Philosophical". For professors, this could be a difficult process, even painful, at times: I was used to students that enjoyed the subject, getting involved, when we were in Pediatrics. Now, according to the evaluation, most did not understand well why this subject and they ask why are there so many hours? Why these themes? ... it has been a painful process for me... but I have not given up, and I will not give up so easily, but it is not an easy process (Professor 3).

Professors also organized themselves to face this paradox situation. With the interaction between professors of the subject and other subjects, and taking into account the assessment of students, they make changes in the subject. Professors use strategies, such as problematizing methodology to decrease abstraction of themes, making the necessary changes in practices, organizing themselves, and being able to make students understand and take part in the process. You start with a perspective and as you develop the proposal, some adjustments are necessary. We are trying to make these adjustments to decrease the level of abstraction of the subject. In fact, we will continue, little by little, with the necessary abstract discussions (Professor 2).

Knowledge is considered as a dialog between us and the universe, and in the real world disorder will never be extinguished, and that will never be extinct: That means that our knowledge is subjective- objective, that phenomenon can be understood when the principles of the four words are matched order/ disorder/interaction/organization, but that continues to be uncertain regarding the real nature of this world $^{(6)}$.

On this perspective, the above mentioned author encourages us to work with uncertainty when he states that "work with uncertainty disturbs many spirits, but enlightens others, making them think and control their thoughts. Encouraging criticizing the established knowledge, considered as the right one. Self-examination is also encouraged and the attempt to self critique ${ }^{\prime(6)}$. In this direction, education must teach the principles of strategies that allow facing risks, the unexpected, the uncertain, and an ocean of uncertainties must be learned through an archipelago or certainty ${ }^{(1)}$.

Ottawa's chart recommends changes in the attitudes of professionals through education processes, a greater effort in health surveys, training and new organization formats ${ }^{(7)}$.

In this study, we have observed that students expect to learn how to interact with people in the Academy, and in practice. To that end, they consider as important, in addition to theoretical classes, to have greater contact with the community, and that this contact should occur from the start of classes. Students value knowledge of the people from the community on the health-disease process, their way of talking, and reacting to diseases. This knowledge, which is passed on from parents to their kids, must be respected when taking care of people, because it has a great value to them: I think popular knowledge is important because it is not completely wrong, I think it is important because we also have to know (Ágata).

Another aspect seen in the present study was the "compartimentation" of subjects, both in Human Living Process I and II, regarding other subjects of the nursing course. That is, subjects are separately developed, with no connections among themselves. For professors, there is lack of communication between the subjects.

Regarding "compartimentation" of subjects we may state that school curriculum is minimal and fragmented $^{(8)}$. Most times there are quantitative and qualitative problems, and there is no view of the whole in these subjects, that do not favor communication and dialog among the knowledge. That is, subjects, each of them with their programs and contents, are 
not integrated or complemented, making the perspective of a set that favors learning.

Students associate the nursing profession with health promotion. They consider it is more connected with the community and that it has to do with dealing directly with people, as well as to develop educational aspects. They believe that nursing education is directed at disease prevention and health promotion, considering education to prevent diseases. They think nurses' participation is essential to work in health promotion, both in hospital, and in the community. $I$ believe that the participation of nursing is essential because of the contact with other people. This role of nursing is preventive, educational, and essential to health (Cristal). I think nurses are totally connected with health promotion (Ouro).

Students in the second phase of the subject Human Living Process II discover gradually the educator role of nurses. We have observed by their expressions in classroom and interviews that students enjoy this educational aspect, and value it as an aspect in which nurses are acknowledged in society. Likewise, they are very pleased when they develop educational projects where they can pass on the knowledge they have learned and where they can learn with the community.

In the study, few students said they have noticed inequality present in the society and that there is a correlation between health and other factors, considered as social determinants of health, such as: proper health, adequate housing, proper diet and hygiene. For these students it is important to make people aware so that they can change their lifestyles.

The focus on health promotion is broader and more encompassing; it tries to identify and face macro determinants of the health-disease process, and transform them favorably towards health ${ }^{(9-11)}$. For health promotion, the continuous object is an excellent life and health level; therefore, the absence of diseases in not enough, since at any health level recorded in an individual there is always something to be done to promote a better health level, and a more satisfactory life ${ }^{(12)}$.

\section{FINAL CONSIDERATIONS}

The Theory of Complexity helped us understand how complex the teaching/learning process is, focusing on health promotion, so we can check the several interconnections presented. It is not easy to develop such a process, neither for professors nor for students because it includes the (de) constructions, constructions, and reconstruction that their social actors need to make in the path.

The teaching/learning process for health promotion is thus developed in a phase of crises going from a state of order (biological thinking of health) to a state of disorder (educating for health promotion), which is uncertain and contradictory regarding what is understood by society as health. To think about complexity, we must consider that the four words: order, disorder, interaction and organization are present in the universe, in human history and its ramifications ${ }^{(6)}$. The author recognizes that in reality there is a concern caused by the casual meeting of two organized phenomenon, just as occurred in the case studied.

The use of GT as a methodological reference enable to show the phenomenon based on the analysis of causal, context aspects, and on the actions or strategies used by professors to develop the phenomenon. Intervening aspects have also been identified hindering actions/strategies and, finally, enabling us to show the consequences of this process.

As a consequence of this process of (de) construction, students interrelated health with society and environment and started to see other ways of health care. Some students became interested in community health to develop health promotion actions as professionals.

We have assessed that, for students, one of the most important aspects of their education is that related with the educational aspect. They value highly the development of educational projects, and are interested on them. These projects are valued because it is where they learn group work, and because they can apply themes that were previously developed in class and pass on their knowledge to the community.

Analysis of the educational community of the Nursing Course is important in this process, especially the need to rethink nursing education focusing on the New Health Promotion, based on social determiners. In this study, a few students mentioned these determiners and/or demonstrated they were aware of their effects in the health population. For what we have observed, students believed that it is enough to teach changing habits to promote health, considering that subjects/members of the community themselves are accountable for their health. 


\section{REFERENCES}

1. Morin E. Os sete saberes necessários à educação do futuro. São Paulo: Cortez; 2004.

2. Strauss A, Corbin J. Bases de la Investigación Cualitativa. Técnicas y Procedimientos para desarrollar la Teoría Fundamentada. Colombia: Editorial Universidad de Antioquia; 2002.

3. Santos LHP dos, Cassiani SHB. Vivendo em constante conflito: o significado da prática docente no ensino médio de enfermagem. Rev Latino-am Enfermagem 2000 outubro; 8(5): 58-64.

4. Ministério da Saúde (BR). Resolução $n^{\circ}$. 196. Diretrizes e normas técnicas regulamentadoras de pesquisa envolvendo seres humanos. Brasília (DF): MS; 1996.

5. Morin E, Almeida MC. Educação e complexidade: Os Sete Saberes e outros Ensaios. São Paulo: Cortez; 2002.

6. Morin E. Ciência com consciência. $7^{\circ}$ ed. Rio de Janeiro: Bertrand Brasil; 2003.

7. World Health Organization - WHO. The Ottawa Charter for Health Promotion. Ottawa, Canada, November; 1986.

8. Petraglia IC, Morin E. A educação e a complexidade do ser e do saber. $8^{\circ}$ ed. Petrópolis: Vozes; 2003.

9. Buss PM. Uma Introdução ao Conceito de Promoção da Saúde. Rio de Janeiro: Fiocruz; 2003.

10. Carvalho SR. Saúde coletiva e promoção da saúde. Sujeito e mudança. São Paulo: HUCITEC; 2005.

11. Lefevre F, Lefevre AC. Promoção de saúde: a negação da negação. Rio de Janeiro: Vieira \& Lent; 2004.

12. Gutiérrez J. Controvérsias disciplinares e compromissos pendentes na pesquisa contemporânea em educação ambiental. Rev Educação Pública 2003; 12(22): 29-37. 